\title{
PREVALÊNCIA DE CÁRIE EM ESCOLARES DE 12 ANOS DE ARAUCÁRIA- PR E SEUS FATORES ASSOCIADOS
}

Gabriela Cristina SANTIN, Tatiana Pegoretti PINTARELLI, Fabian Calixto FRAIZ, Fernanda de Morais FERREIRA

Este estudo transversal investigou a relação de fatores socioeconômicos, comportamentais, biológicos e de acesso a serviço odontológico com a presença de dentes cariados não tratados (DCNT) em escolares de 12 anos de Araucária- PR. Os adolescentes ( $n=589)$ selecionados aleatoriamente em amostragem por conglomerado participaram de teste para o paladar doce, responderam questionário de freqüência de consumo de alimentos com sacarose e tiveram os níveis salivares de estreptococos do grupo mutans (SM) e lactobacilos (L) estimados. Dados socioeconômicos e de acesso foram obtidos por questionário enviado às mães. Avaliou-se higiene bucal e presença de DCNT através dos índices IHO-S e CPOD, por examinador calibrado. O modelo múltiplo de regressão de Poisson demonstrou que adolescentes com higiene bucal insatisfatória, altos níveis de SM e L, consumo superior a três alimentos/dia com sacarose, renda familiar inferior a 2,4 salários mínimos e mães cujo motivo da última visita ao dentista foi curativo apresentaram maior prevalência de DCNT $(p<0,05)$. Em escolares de 12 anos deste município, as variáveis que melhor explicaram a presença de DCNT foram higiene bucal insatisfatória, presença de grupos bacterianos acidogênicos e acidúricos específicos, dieta rica em sacarose, baixa renda e busca materna por atendimento odontológico apenas curativo.

Palavras-chave: Cárie Dentária; Adolescente; Fatores de Risco. 